\title{
The Supreme Constitutional Court of Egypt: The Limits of Liberal Political Science and CLS Analysis of Law Elsewhere
}

Lama Abu-Odeh

Georgetown University Law Center, la34@law.georgetown.edu

This paper can be downloaded free of charge from:

https://scholarship.law.georgetown.edu/facpub/1636

59 Am. J. Comp. L. 985-1007 (2011)

This open-access article is brought to you by the Georgetown Law Library. Posted with permission of the author. Follow this and additional works at: https://scholarship.law.georgetown.edu/facpub

Part of the Comparative and Foreign Law Commons, Jurisprudence Commons, and the Law and Politics Commons 


\section{LAMA ABU ODEH*}

\section{The Supreme Constitutional Court of Egypt: The Limits of Liberal Political Science and CLS Analysis of Law Elsewhere $\dagger$}

On January 25th 2011, following a popular uprising, president Hosni Mubarak of Egypt was forced to relinquish power after thirty years of continuous rule. The popular uprising came to be known as the Egyptian revolution of January 25th marking the first time in the modern history of Egypt an authoritarian ruler is forced out of power through the mobilization of Egyptian masses. The popular mobilization came at the heels of several years of "wildcat" workers' strikes affecting various sectors of the economy, public and private, as well as recurring demonstrations spearheaded by the youth of the Egyptian middle class demanding civil and political rights and protesting the intrusive rule of security. This Article discusses the role the Supreme Constitutional Court (SCC) of Egypt played in framing through its jurisprudence the economic and political picture in the two decades preceding the revolution and that arguably contributed to the precipitation of the events leading up to the revolution.

The SCC itself was not immune to the intrusive reach of the reign of "security" of Mubarak's authoritarian rule even though the regime supported the court's autonomy in the early years of its adjudication. While the SCC facilitated the transition to "neoliberalism" as the Mubarak regime had hoped it would, it also took the regime by surprise both by its sometimes extreme libertarian approach to economic issues as well as its liberal(izing) jurisprudence on the political side, creating serious dilemmas for the regime. Gradually, the composition of the court was modified to ease off the bite of the jurisprudence the court developed in the 1990s.

Egypt is now going through a constitutional transition. On March 19, 2011, Egyptians approved a number of constitutional amendments that would allow for the first post-Mubarak democratic elections to be held in November of 2011. In the aftermath of the elections, a commission will be formed to draft a new constitution commemorating the

* Professor of Law, Georgetown University Law Center, LL.B., University of Jordan; LL.M., University of Bristol, UK; MA Philosophy, University of York, York, UK; S.J.D., Harvard Law School.

$\dagger$ DOI 10.5131/AJCL.2011.0014 
event of revolution. A referendum will take place to vote on the new constitution.

The fate of the SCC with its current organizing law and membership $^{1}$ remain uncertain. What a constitutional court in a postrevolutionary context, in which political practice is free and ideologies "run wild" without the constraint of security, would look like remains to be seen. How much of the SCC's jurisprudence carries over to the new era also remains an open question.

The Article was written before the revolution took place. I will preserve its pre-revolution time-voice and hope that the reader treats it as a piece on the "intellectual history" of law, judges, and jurisprudence in Egypt in the decades leading up to revolution.

\section{INTRODUCTION}

This Article is an attempt to provide a "thick" analysis of an instance of constitutionalism elsewhere. The instance is that of the jurisprudence of the Supreme Constitutional Court of Egypt (SCC) in its heyday in the 1990s characterized by the court's robust attempt to bring about a double liberalization through its jurisprudence: one of the economy and one of politics. While it was the previous authoritarian regime of Mubarak that empowered the court to perform precisely these tasks: to assume the blame for the shift to neoliberalism in the economy, as well as to "loosen" the political sphere so that the "pain" from liberalization can take some form of political expression, ${ }^{2}$ the earnestness and enthusiasm of the SCC surprised the regime. The SCC's 1990s jurisprudence surpassed the limit of liberalization the regime was willing to tolerate, leading eventually to the replacement of the Chief Justice of the court with a regime insider.

This Article argues that the court's neo-liberalizing decisions of the period, extreme and uncompromising in some instances, as well as the unfolding struggle for its autonomy in the face of an intrusive authoritarian regime created a surprising trade-off in positions between the regime and the left. The left traded-off its conventional concern over distributional outcome for one over "the rule of law" intensifying thereby its faith in, and attachment to, the latter,

1. Article 175 of the Egyptian Constitution of 1971 provides, "The Supreme Constitutional Court reviews the constitutionality of laws and regulations, interprets legislative provisions, all according to the law. The law regulates the other areas of jurisdiction of the court and the procedures followed in the trial of cases before it." See the Constitution of the Arab Republic of Egypt 1971. English translation available at http://www.sis.gov.eg/En/LastPage.aspx?Category_ID=208 (last visited July 30, 2011). Law No. 48, Year 1979 regulates the affairs of the Supreme Constitutional Court, including the appointment and nomination of its Chief Justice and member Justices.

2. See Tamir Moustafa, The Struggle for Constitutional Power: Law, Politics, and Economic Development in Egypt (2007). 
ironically leaving concern over distributive outcome to the regime in the name of "law and order" or "security considerations." This trade off occurred as a result of, on the one side, the selective use of the court by a good number of human rights organizations to push for doctrinal transformation in areas they read would be agreeable to an overall liberalizing court and then rallying behind the court when its autonomy was threatened by the regime, and on the other, the serious threat to the revenue stream of the regime that the relentless neo-liberalizing of the economy by the court was creating, undermining its capacity to manage the outcome of such liberalization.

Complicating the picture, the Article argues that in lieu of "ideology" as the form in which distributional concerns are typically rationalized and legitimated, "law and order/security" has become the form in which such concerns are not so much legitimated as managed in the neoliberal era. This has serious analytical consequences for our understanding of the behavior of a court that adjudicated against a background of security-in-lieu-of-ideology. Such a court could only act politically no matter how technocratic or formalist its judicial decisions may have appeared. Absent ideology, the distance between politics and law is a very short one.

If we add the court to the trade-off of positions described above, we find ourselves confronting a very unfamiliar situation particularly if we have the comparative case of the United States in mind: the regime concerned with distribution in the name of "law and order," the left preoccupied with the "rule of law" at the expense of distribution, and the court acting openly politically behind the thin veil of its technocratic legal language.

The Article further argues that this triangular trade-off is left analytically unaccounted for by a liberal legal and political science discussion of the court because of this literature's normative sympathy to the double liberalizing project of the court: introducing market and democracy through constitutional interpretation is a rightful project, according to this literature, that should be applauded. A form of conceptual glibness about distributional outcomes for marginalized social groups therefore ensues and an inability to note them analytically especially in the positions of the primary actors.

On the other side, the trade-off raises questions for someone who is interested in knocking down faith in the "rule of law" from the CLS perspective. This is so because of the confusion produced by this trade-off: putting faith in the rule of law on the side of the left which in the context of the United States, home of the CLS critique, is the very agent of critique of such faith, and the concern for distribution on the side of an authoritarian regime, typically the concern of the left, and the absence of the category of "ideology" to separate the court's legal reasoning from political influence, and its displacement 
by the category of "security"-a situation starkly different from that of the United States where judges are beholden to the faith in the rule of law with a background of ideological influence.

The Article is divided into three parts:

Part One provides a representation of the dynamic interaction between the Court, the political left and the regime that accounts for the trade-off, with an implicit critique of the representation adopted by political science of such a dynamic.

Part Two provides an argument for the limits of the use of CLS analysis to understand this dynamic. I argue that the shift in the roles/ positions makes critique superfluous. More specifically, I argue that the absence of "ideology" and its displacement by "security considerations" means the main problem for judges is not "indeterminacy," but rather the influence of the security forces, i.e., the lack of judicial autonomy.

Part Three provides a historical account of the political economy of Egypt to explain the shift from ideology to security. I argue that Egypt has moved from an ideology of nationalist socialism to the nonideology of "security plus rentierism ${ }^{3}$ " as a result of the failure of Import Substitution Industrialization (ISI) ${ }^{4}$ and its displacement by

3. Rentierism refers to an orientation in the political economy of a state whereby the state derives all or a substantial portion of its national revenues from the rent of indigenous resources to international clients. The sources of rent in the case Egypt are: the sale of natural gas in international market, rent collected through use of the Suez Canal by international shipments, and USAID in which Egypt rents its geostrategic location to the United States. See Hazem Beblawi \& Giacomo Luciani, The Rentier State (1987).

Because the rent collected by the state from such resources is high given the "strategic" value attached to the product being sold (natural gas, Suez canal, geostrategic location) and because the state under these circumstances deploys a minimal of its national labor to extract such resources, the state expends the rent on its nationals as bounty rather than as reward for labor. The rentier state relates to its citizens through the non-ideological relation of reward and gratitude (empty ideology) while the coercive state is tied to its citizens through the empty but heavy relationship of the coercion of terror. In the neoliberal era the Egyptian regime was tied to its citizens through the combined ideological vaccum of coercion and rentierism. See NAZIH Ayubi, Overstating the Arab State 228 (1995).

4. ISI is a development strategy based on introducing industrialization within a particular national territory by structuring a subsidy and tariff system aiming at protecting local infant industries from the competition of industrial imports. The strategy is based on reorienting rural labor to cities and towns to engage in industrial work and in taxing both national consumers and farmers to subsidize the emergent industrial elite and industrial working class. In effect, the consumers pay higher prices for (initially) lower quality goods (compared to imports) and farmers selling their agricultural output at a discounted price in order to subsidize the wages the new industrial elite is paying its nascent industrial working class. The success of the strategy depends on treating ISI as an initial stage of production to be followed by one of competition so that the previously subsidized industrial goods are no longer protected but are forced to compete with other industrial goods in the international market. Failure of ISI typically denotes a situation in which the transition to the competitive stage is never realized with the result that the social subsidy to the local industrial class continues usually through collaboration of a corrupt political class that facilitates the stalemate in the economy and the continuation of the unjust and 
neo-liberalism. This shift has created a huge surplus of grievance that could only be overcome by coercion of the losers and bribery of a huge civil service through rentier money to control the edges of discontent.

\section{PART ONE}

\section{A. The Heyday of the Court}

The story of the Supreme Constitutional Court of Egypt (SCC) is an interesting albeit tragic one. The court remains a working institution in Egypt, located in a spectacular building in Maadi, Cairo, manned by elite judges who continue to churn out decisions vital to the nation, receiving visitors interested in human rights in Egypt and occasionally attracting newspaper headlines. Yet, one may nevertheless be justified in referring to the Court in the past tense. There was an SCC in Egypt. The contemporary SCC seems more like a faint shadow of its previous self, especially the one that thrived and throbbed in the 1990s: earning the ire of the Mubarak government, the admiration of human rights activists and political partisans of the opposition, and the ambivalence- mixed-with-exasperation of law professors and other members of the judiciary. ${ }^{5}$ In the 1990 s SCC was the talk of the town!

For very good reasons. The successive rulings of the court opened up electoral candidacy, party registration, freedom of expression, and human rights advocacy, ${ }^{6}$ creating a sense-in a country like Egypt

burdensome subsidy that enriches the few and stalls the overall development of the economy. See James M. Cypher \& James L. Dietz, The Process of Economic Development $\S 248-79$ (3d ed. 2008).

5. The SCC was criticized by Egyptian law professors for various reasons, including, among others: its departure from the civilian legal tradition in its approach to legal interpretation and reasoning and reorienting the source of influence to that of American constitutional jurisprudence, ignoring the socialist orientation of the Egyptian Constitution, making strict liability in matters regulating commerce unconstitutional, adopting an extreme attitude towards taxation by insisting on formal equality among those taxed, disrupting the attempt by the state to facilitate tax collection, and prevention of tax evasion by declaring such attempts unconstitutional. For a collection of articles in which these criticisms are made, see Role of the Supreme Constitutional Court in the Egyptian Legal System, First Conference for the Faculty of Law, Helwan University, 1998.

6. For example, see Case 59, Judicial Year 18, issued Feb. 1, 1997 [SCCDC, Vol. 8 , $p$ 286], the court struck down legislation that excluded certain categories of citizens from joining political parties and participating in political activities, since it violates constitutional rights of multi-party system and participating in public life. The court held that although the pertinent legislation was accepted by referendum called by the President of Egypt, it remains inferior in rank to the Constitution; Case 37, Judicial Year 11, issued Feb. 6, 1993 [SCCDC, Vol. 5, Part 2, p 183], on the limitation of seats for independent candidates in the elections to the People's Assembly. The court held that the discriminatory factors outlines in Article 40, i.e., race, ethnic origin, religion or creed, are not comprehensive but indicative. Thus election arrangements that discriminate on basis of social or economic class, adoption of political or non-political views, or affiliation to a particular minority group, violate the equal protection clause 
where oppositional political activity is stifled-that politics was at last possible, only, well . . . in a roundabout kind of way: rather than through open confrontation on the streets with the powers that be (as in Iran), ${ }^{7}$ political life came through the courts! The SCC 's "in-yourface" rulings created among many Egyptians the sense, and a rather paradoxical one at that, that through rule of law constitutionalism, they were delivered the political! And by God, they wanted both: the political and the rule of law. How amazing that they could get them both in one irresistible package through the court, the one in the guise of the other! "Rights" was not only the new name of politics but also that of the rule of law. And so activists flooded the court, populating its hallways with their briefs pushing the court to push the regime to deliver them more and more politics/rights. ${ }^{8}$

Commentators caught on, lawyers and political scientists alike. Perusing the literature produced by both, one is impressed with the praise it showered on the SCC..$^{9}$ Both groups discuss the court admiringly, whether with regard to its stance on Islamic law

and is thus unconstitutional. In Case 2, Judicial Year 9, issued Feb. 1, 1992 [SCCDC, Vol. 5, Part 1, p 142], the court held that legislation that arbitrarily discriminates between individuals without objective foundations violates the equal protection principles enshrined in Article 8 and 40 of the constitution; Case 34, Judicial Year 13, issued June 20, 1994 [Official Gazette No 27, July 7, 1994], on the unconstitutionality of legislation interpretation that included additional conditions in Social Security Law, which narrows the scope of pensions for various salaried workers in order to relieve the state's financial burden; Case 44, Judicial Year 7, issued May 7, 1988 [SCCDC, Vol. 4, p 88], the court struck down legislation that prohibited the establishment of political party-the Nasserist Party-for criticizing a treaty-the peace treaty between Egypt and Israel - due to the violation of constitutional rights of freedom of expression, multi-party system and the democratic character of the state. Basically, all the political parties in Egypt are creations of the courts, due to a simple fact that the Political Parties Committee, controlled by the regime, granted only the National Democratic Party (NDP) the regime party, a license. See Joshua Stacher, Parties Over: The Demise of Egypt's Opposition Parties, 31 BRIT. J. Middle E. STUd. $215,218-22$ (2004).

7. Of course, it was the confrontation on the streets with an authoritarian regime that eventually opened up the political in Egypt-January 25th revolution.

8. See Case 42, Judicial Year 11, issued May 20, 1995, dealing with freedom of expression. The court held that criticizing public actions through the press, or other means of expression, is a right guaranteed to every citizen and an essential principle of democracy. On the same principles, see also Case 37, Judicial Year 11, issued Feb. 6, 1993 [SCCDC, Vol. 5, Part 2, p 183]. On the freedom of press, see Case 25, Judicial Year 16, issued July 3, 1995 [Official Gazette No 29, 20th July 1995]. See also Case 44, supra note 6.

9. See Moustafa, supra note 2; Nathan Brown, Judicial Review and the Arab World, 9 (4) Journal of Democracy 85-99 (Oct., 1998); Nathan J. Brown, The Rule of LAw in the Arab World: Courts in Egypt and the Gulf (1997) (hereinafter Brown, The Rule of Law in the Arab World]; Democracy, the Rule of Law and IsLAM (Eugene Cotran \& Adel Omar Sherif eds., 1999); Clark B. Lombardi, Islamic Law as a Source of Constitutional Law in Egypt: The Constitutionalization of the Sharia in Modern Arab State, 37 Colum. J. Transnat'l L. (1998); Ran Hirschl, ConSTITUTIONAL THEOCRACY (2010). 
(secularization), ${ }^{10}$ or its stance on human rights (pushing the boundaries of an authoritarian regime ${ }^{11}$ ) or its stance on economic issues (getting the incentives right so that economic development and growth can be triggered in Egypt ${ }^{12}$ ). The admiration is typically directed at the court's jurisprudence in the 1980 s but especially in the $1990 \mathrm{~s}$, the time when the court used the autonomy it earned hard by delivering judgments the regime was in need of (in the area of the economy) to reign in the powers of that same regime (in the area of civil and political rights). The regime assaulted this autonomy in the

10. See Case 8, Judicial Year 17, issued May 18, 1996 [SCCDC, Vol. 8, p 657], dealing with the right of Muslim women to wear "niqab" (full veil), the court held that the Minister of Education decree that prohibited students from wearing "niqab" while attending public schools is constitutional; the court ruled that the decree did not interfere with any fundamental requirement of Islam. On this case, see also Nathan J. Brown \& Clark B. Lombardi, Supreme Constitutional Court of Egypt on Islamic Law, Veiling and Civil Rights: An Annotated Translation of Supreme Constitutional Court of Egypt Case No. 8 of Judicial Year 17 (May 18, 1996), 21 AM. U. INT'L L. REv. 437 (2006). See also Case 7, Judicial Year 8, issued May 15, 1993 [SCCDC, Vol. 5, Part 2, p 260 ], on enhancing rights of a divorced woman and her children by authorizing the legislator to freely regulate measured alimony according to the best interest of the society. Similarly, in Case 29, Judicial Year 11, issued Mar. 26, 1994 [SCCDC, Vol. 6, p 231], the court enforced the father to make payments to the mother dating back to about twenty years for her guardianship of their infant child. For more analysis on the SCC ruling on Islamic cases, see Clark B. Lombardi, Islamic Law as a Source of Constitutional Law in Egypt: The Constitutionalization of the Sharia in Modern Arab State, 37 Colum. J. Transnat'L L. 81 (1998); Lama Abu Odeh, Modernizing Muslim Family Law: The Case of Egypt, 37 Van. J. Transnat'L L. 1043 (2004); Clark B. Lombardi \& Nathan J. Brown, Do Constitutions Requiring Adherence to Shari'a Threaten Human Rights? How Egypt's Constitutional Court Reconciles Islamic Law with the Liberal Rule of Law, 21 AM. U. INT'L L. REv. 379 (2006).

11. In a landmark case in constitutional law-making in Egypt, Case 37, Judicial Year 9, issued May 19, 1990 [SCCDC, Vol. 4, p 256], the court emphasized that the constitution is the fundamental which lays down the norms, rules and functions of the regime, and it also guarantees individual rights and liberties, equal treatment before the law, the right to participate in public life, and reassured the importance of a multi-party system. Along these lines the court held in Case 56, Judicial Year 6, issued June 21, 1986 [SCCDC, Vol. 3, p 353], that excluding certain categories of citizens from the political process was unconstitutional. See also Case 23, Judicial Year 8, issued Apr. 15, 1989 [SCCDC, Vol. 4, p 205], on restricting candidacy for public office to political parties, and ruled that exclusion of independent candidates from becoming members of representative assemblies is unconstitutional.

12. In Case 3, Judicial Year 1, issued June 25, 1983 [SCCDC, Vol. 2, p 155], struck down legislation which provided that farm land can be taken by the government without compensation, that it violates the owner private property and thereby imposing a form of confiscation, and thus is unconstitutional. Similarly, the court explored along these lines in Case 1, Judicial Year 1, issued Mar. 2, 1985 [SCCDC, Vol. $3, p$ 161], the legal and rational basis for safeguarding the right of private property as an incentive for progressive activity by individuals as well as being a source of national wealth, thus the court prohibited nationalization unless it is for public interest, in accordance with law, and suitable compensation. Likewise, in Case 22, Judicial Year 12, [Official Gazette No 3, Jan. 1, 1994] the court noted the limits within which private property is to be protected with regard to the lease and sale of premises and the regulation of the relationship between the lessor and lessee. On cases pertinent to dismantling rent control in residential buildings, see Case 44, Judicial Year 17, issued Feb. 22, 1997 [SCCDC, Vol. 8, p 394], allowing tenants' relatives to inherent the tenancy contract; in Case 71, Judicial Year 19, issued Oct. 4, 1997 [SCCDC, Vol. 8, p $876]$, the court allowed tenants to exchange their tenancies in rental units. 
new millennium when it moved aggressively and appointed a series of presidents to the court that came from the heart of the regime, some of whom had worked hard in previous capacities to undo the work of the court during the $1990 \mathrm{~s}^{13}$

So the once promising light emanating from the SCC no longer shimmered and its full-of-hope politicians-cum-lawyers crowding its hallways withdrew to the background, tail between their legs; briefs returned to briefcases and the international in human rights agenda back to the international.

\section{B. In the Nature of the (Authoritarian) Beast}

"Of course, it's dead, what do you expect?", one can hear the reader scream! "Egypt lives under the reign of an authoritarian regime! Whoever thought that the rule of law and rights based constitutionalism could even be possible in such a system? Isn't that a contradiction in terms?? It is amazing that the SCC survived for as long as it did!" And so indeed is the story of the rise and fall of the SCC typically told: following the collapse of its economy and the accumulation of its debt to international creditors, an authoritarian regime heeding the advice of the World Bank, establishes a constitutional court. The role of the court is to reassure potential foreign investors that their property rights will be protected. The SCC did exactly that, the story is told, but did much more than that. And it is the "more" that was its undoing. The court pushed too hard and challenged the regime in directions it hadn't foreseen (liberalizing the political). ${ }^{14}$ While the calculation of the World Bank economists providing the advice was that protection of private property (i.e., the market economy) would lead to the domino effect of rule of law, economic growth and inevitably democracy, this didn't exactly pan out in the Egyptian case. Why is that? Well, because these economists, the wisdom goes, missed two facts: one about the nature of courts (judges tend to usurp autonomy for themselves making the outcome of their decisions unpredictable for the regime); and one about the nature of authoritarian regimes (they tend to "eat their babies": even onceupon-a-time-useful courts are expendable when the power of the regime is at stake). ${ }^{15}$ And so instead of a domino effect, we have rule of law interruptus.

13. In 1998, Awad al-Murr, the Chief Justice of the Court, under whose presidency the court delivered most of its liberalizing jurisprudence, retired and was replaced by Chief Justice Muhammad Wali al-Din Galal. In 2001 and after, the retirement of CJ Galal, Fathi Nagib became Chief Justice of the Court, a "man who held the second most powerful post in the Ministry of Justice ... . [and] had drafted the vast majority of the government's illiberal legislation." See Moustafa, supra note 2, at 19899.

14. See Moustafa, supra note 2, at $178-218$.

15. See generally Brown, The Rule of LaW in the Arab Wortd, supra note 9. See also Moustafa, supra note 2, at 219-37. 


\section{An Alternative Account of the History of the SCC}

This Article provides an alternative, almost reverse, account of the rise and fall of the SCC. It does so by reading the history of the SCC backwards, so to speak, i.e., by reading the past of the court through its present. ${ }^{16}$ It is the post-court that tells the story of the court in its heyday most accurately. The conventional account of the SCC considers the capture of the court's presidency by the regime to be a significant event, the aftermath of which is not worth telling. After all, once the death bell of the rule of law tolls, what is there to say?

What is notable, however, is that, as human rights activists withdrew to the background and the SCC's light no longer shimmered, new actors took the political/legal stage. Those new actors seem to replace the old trio of SCC, human rights activists/political opposition and government, embodying in their presence and list of demands a radical critique of the era of the SCC that had been heralded by its fans as a new and welcome dawn in Egypt. Those new actors, I argue, hint at what was grossly missing in our consideration of the era of the SCC. Egypt is rocked by labor protests. Every day, it seems, a new local site of labor protest comes to the fore with protestors demanding pay raise, free lunch, break time, paid leave, safe work conditions, cessation of gender inequality, etc. The faces of the leaders of those highly localized but numerous protests are unfamiliar just as those of the protestors themselves. What is notable about these sites of protest is an absence and a presence: the absence is that of the human rights activists that had carried briefcases and crowded the hallways of the SCC in the 1990s; they just don't seem to be there. The presence? Representatives from the Egyptian security services negotiating with these local (unheard-of-before) leaders and often making concessions to the protestors. ${ }^{17}$

So what is the meaning of this shift and what exactly does it tell us about the SCC?

16. The "present" is a reference to the time after the court's retreat but before the revolution of 2011 .

17. In his article on "Security and Politics," an article posted on the website of the Democratic Front Party, illustrates the reciprocal relations between the State and the Security forces under Mubarak, and shows how the failure of the State increases the power of the Security forces as an alternative ruler. Thus the absence of the political leadership during the labor strikes brings the security forces to fill the vacuum by running the negotiations with the striking labor on behalf of the state. See http:// www.democraticfront.org/index2.php?option $=$ com_content\&task=view\&id=173\&pop= $1 \&$ page $=0$ (last visited July 20,2011). On the role of the security forces as the main negotiator with the striking labor, see also the report of the Center for Socialist Studies, which enlists several labor protests in different places in Egypt, pointing out the negotiations that took place between the labor and the security forces, available at $\mathrm{http}: / /$ www.e-socialists.net/node/999 (last visited July 20, 2011). 
With all the excitement that surrounded the court in its heyday, very few seemed to appreciate the radicalism of its agenda and if they did, their judgment of the SCC's radicalism was misplaced. The (mis)place of the excitement for the court seems to have been its jurisprudence on "the political." The rulings the court delivered during that period (i.e., the 1990s) improved the bargaining power of the human rights activists/political opposition vis a vis the government and this seemed to incense the regime. It is this rage that suggested that the court's radicalism was located in the "political." Sure enough, some were disappointed that the court didn't go further than it did by declaring "security and emergency courts"18 unconstitutional, but everybody understood that the margins of maneuver for a constitutional court in an authoritarian regime were limited especially if it wanted to stay in action.

In fact, however, the place of the SCC's radicalism was its economic jurisprudence: its rulings on taxes (highly libertarian), agricultural reforms (reversing them), tenancy on residential buildings (reversing rent control), privatization of public sector companies (re-interpreting a "socialist" constitution to approve of it), reversing the effects of past nationalization and sequestration of property (forcing government to pay market value for sequestered or nationalized property), etc. These rulings are radical because they had a massive redistributive impact and ultimately pushed the regime to a precipice: on the one hand, the rulings lead to the creation of economic losers (peasants, tenants, workers, surplus non-workers) who were not too happy with their new diminished status, and on the other, the rulings, by chipping away at government's precious revenue, undermined the ability of the government to control the ire of those economic losers through "law and order."19 While the Mubarak re-

18. See Nathan Brown, Michael Dunne \& Amr Hamzawy, Egypt's Controversial Constitutional Amendments, Carnegie Endowment for International Peace, Mar. 23 , 2007, available at http://www.carnegieendowment.org/files/egypt_constitution_ webcommentary01.pdf (last visited July 19, 2011). See also NaTHAN BROWn, Constitutions in a Nonconstitutional World: Arab Basic Laws and the Prospects for ACCOUNTABLE Government (2002).

19. Supreme Constitutional Court rulings on property rights claims had drained state coffers of billions of Egyptian pounds. Pending cases on the SCC docket had the further potential to make the early property rights rulings pale by comparison. Most significant were ninety-two petitions on the Court docket contesting a variety of provisions of the sales tax law. Minister of Justice Seif al-Nasr estimated that pending rulings could cost the state up to $£$ E 7.7 billion (approximately $\$ 2.3$ billion). The Constitution Court was effectively fulfilling its mandate of protecting property rights against governmental infringements, but would the government continue to abide by its ruling? The answer to the question came in 1998 with the first concrete struggle over Supreme Constitutional Court independence. In July of that year, the government attempted to protect itself from pending challenges in the sphere of taxation. Mubarak issued a presidential decree that restricted retroactive compensation claims as the result of SCC taxation rulings to the party initiating the constitutional petition. 
gime created the SCC in the first place to do exactly all of the above, i.e., introduce a market economy full force, the SCC's consecutive unrelenting judicial whippings in that direction put the regime face to face with the terrifying impact of these rulings, tying its hands in a doubled sense: producing losers, and disabling the government to deal with them effectively. ${ }^{20}$

\section{A Demonic Trade-off: Redistribution as the Concern of the Authoritarian Regime, Rule of Law as the Concern of the Left}

What seems odd is that while the tug of war over the political jurisprudence of the court was taking place in the 1990s, whose much-too-much sung heroes were human rights activists, it was only the government that was staring the redistributive impact of the economic jurisprudence in the eye, in the form of a "law and order" problem. While the court was mired in its battle with the regime, the issue that gripped everybody's attention-from activists, to parties of the opposition, to commentators-was the question of the court's autonomy threatened by the regime's resistance to political liberalization. While the court's economic jurisprudence was piling up classes of losers, all eyes turned to the SCC's loss of autonomy as the most terrible of all possible losses. ${ }^{21}$ The opposition and its allies, it seems, were only interested in one loser: the SCC (the producer of the losers whose interests they were supposed to represent in the political!).The effect of all this? An odd and demonic, albeit indirect, tradeoff: the opposition transfers the concerns over wealth distribution to the regime (in the name of law and order), while the regime transfers the concerns over the security of the market economy (indirectly) to the opposition and human rights community (in the name of rule of law!).

Some commentators have noted the regime's ingenious device of introducing private property as a court-based initiative thereby projecting its will to liberalize the economy unto the court, transferring

See Moustafa, supra note 2, at 179.

20. The capacity of the government to manage discontent through increased security-based repression and/or through symbolic welfare hand-outs was undermined by the loss of revenue. Supra note 19 .

21. Moustafa illustrates how the civil society, i.e., opposition, the legal profession, human right groups and NGOs, became the "judicial support network" for the SCC, which was perceived as the most promising avenues to promote a political reform agenda. Hence, the civil society shifted its strategy to constitutional litigation, where the SCC provided an effective and successful avenue in challenging the regime and defending their interests. Moustafa argues that constitutional litigation besides challenging the regime legislation it aimed to expand the legal foundation of the civil society itself. The exclusive dependency of the civil society on litigation made their focal point to protect the SCC independence. See Moustafa, supra note 2. 
blame to it for the consequences. ${ }^{22}$ In fact, for the economic losers, losing through constitutional interpretation was only one side of the pincer inside which they found themselves caught; the other side was the substitution on the part of the opposition (especially the left) of the call for justice with that for the rule of law! One might say therefore that it is through turning a blind eye to issues of distribution generated by the court and preoccupation with the court's autonomy that rule of law as a left agenda was initiated in Egypt. One was given up for the other, or one might say, that the dark side of the "rule of law" for Egypt was "the in-justice of private property." And since the issues that brought the question of the court's autonomy to the fore were related to the court's political jurisprudence (constitutionalizing the trappings of democracy), one might add that the dark side of "democracy" for Egypt is "the in-justice of private property."

\section{E. Tightening the Interpretive Noose: Amending the Constitution}

In 2007 , the regime amended the constitution to abolish all references to socialism (also significantly narrowing down avenues of political participation). While the SCC, in the heyday of its autonomy, and before the introduction of these amendments, performed interpretive acrobatics to introduce market economy in its decisions against the letter of an openly "socialist" constitution, now, a much less autonomous court has the constitution on its side so to speak. Today, economic losers are face to face with private property without the song and dance of rule of law constitutionalism much as the political losers are face to face with authoritarianism without the song

22. By 1979, the year that the Supreme Constitutional Court was created, total external debt had reached $\$ 15.4$ billion, and debt servicing consumed fifty-one percent of all export earnings. The Egyptian economy was a virtual time bomb, and the political survival of the regime hung in the balance. The specter of the 1977 food riots was on the mind of Sadat as he searched for more ways to attract foreign investment. It was in this context that the new Supreme Constitutional court was established on August 29, 1979. Mahmud Fahmy, one of the main architects of the economic opening and member of the committee that drew up the first draft of the Supreme Constitutional Court Law, recalled that

the establishment of the Supreme Constitutional Court was really the result of internal and external pressure. From inside, the legal profession was pushing and they were very upset about the old Supreme Court because it was really a tool to legitimize the government's acts and views and it was not an independent body. But more importantly, from the outside there was pressure from foreign investors and even the foreign embassies. They all said, "you are crying for investments to come but under what circumstances and with what protections?"

Fahmy concluded that "the establishment of the Supreme Constitutional Court was part of a bundle of legislative reform at the time. It [the establishment of SCC] was intended by Sadat to keep the foreign investors at ease." See Moustafa, supra note 2, at 77. See also Adel Omar Sherif \& Nathan J. Brown, Judicial Independence in the Arab World, Program of Arab Governance of the UNDP (2002), available at http:// www.undp-pogar.org/publications/index.asp?tid $=9 \&$ src $=1 \&$ type $=0 \& s 0=0$ (last visited July 19, 2011). 
and dance of the rule of law constitutionalism (witness the emergency/terrorism laws). The difference is that much commentary is founded on the latter and hardly any on the former.

Come the representative of Egyptian security services negotiating directly with leaders of labor protests.

\section{F. Critique of the Court}

\section{An Alternative Fairy Tale Scenario}

Let us imagine for a moment that the opposite had taken place. Instead of liberalizing the economic sphere to suit the agenda of the regime and its international financial sponsors, and using the credit it accumulated in the process to liberalize the political realm, the SCC constitutionalized the regime's hold on the latter (kept political party laws, electoral laws, censorship laws, etc., intact) but used such credit to properly "socialize" the economy in a way that corresponds with the letter of the constitution (before its amendment in 2007). In other words, let us imagine that the SCC decided that what should have been a properly distributive and representative constitution was rendered inoperative by a corporatist regime that transformed the institutions of Import Substitution Industrialization (ISI) into state capitalism without industrialization (i.e., failed ISI). ${ }^{23}$

To explore fully the implications of this imaginary scenario, it is worth first asserting that the strategy by the real SCC of nurturing the human rights activist community so that it comes to the court's defense if it were threatened by the regime, as one commentator put it, had a deep dark side ${ }^{24}$ : human rights activists fashioned themselves and planned their interventionist agendas after the court's jurisprudence, pushing the jurisprudence only in areas they thought the court would be sympathetic to (civil and political rights) and shied away from those they learned, the hard way, would be met with little sympathy from the court (the economic, specifically representing the economic losers of the introduction of neoliberalism in the economy by the court). Consequently, one can confidently state that

23. Many countries, including Egypt, who had adopted ISI as an economic strategy relying on public sector-led industrialization, ended up not only failing to industrialize but also transforming the public sector into a place of corruption and enrichment for state elites, "state capitalism." The political regime that oversees the failure of ISI is typically an authoritarian one that relies on "corporatized" political entities, i.e., parties, unions and associations that are either dominated by the regime or affiliated with it. See in general Anne O. Krueger, Political Economy of Policy REFoRM In DEVELOPING CounTRIES (1993).

24. Moustafa argues that by 1997 the constitutional litigation strategy that successfully managed to defend human rights became the dominant strategy. Actually, the SCC encouraged human rights cases through its liberal decisions. However, attempts to safeguard the last vestige of Nasser-era economic rights for the poor were marginalized, since the activists knew that the possibilities of successfully defending these rights through the SCC are slim. See Moustafa, supra note 2, at 145- 54. 
the SCC made its human rights groups and didn't exactly find them. It is as if the SCC split off part of itself and deposited it in the human rights constituency that litigated before it, mirroring thereby itself back to itself. And so what the court didn't offer in jurisprudence it didn't get in human rights litigation and vice versa. It is true that around the particular jurisprudence/human rights cluster that ensued, a great deal of excitement was created, a certain je ne sais quoi, of hopeful possibility and a waiting to exhale, but it is also true that what was absent from the cluster was equally telling of the court.

In the alternative fairy tale scenario, the court would garner a different set of litigants and a different gendarme of activists. It would be approached by plaintiffs/human rights activists representing farmers litigating the unfair price at which the government was buying their agricultural products and the unconstitutional criteria used for agricultural loans by government-owned agricultural banks; or factory workers litigating the unconstitutional measurement of their wages especially with regard to profits generated by factories of the public sector where they work and relative to profits and salaries recouped by (corrupt) management; by the poor of the "random" neighborhoods ${ }^{25}$ litigating the lack of public infrastructure, $a$ la lettre of the constitution, of (sewage, water, roads) in their neighborhoods, etc. In this imaginary (fairy tale) alternative scenario, we would have seen a completely different human rights activist emerge responding to a substantively different type of constitutional jurisprudence. One can imagine such an activist birthed from the bosom of left politics in Egypt using rule of law constitutionalism to undo a system of legislation/state organization that has "corporatized" the left" and "capitalized" the public sector. ${ }^{27}$ That is not to say that the SCC would not have been "shut down" soon enough by having its autonomy usurped, as it really happened. But the political consequences, I would wager, would look different after the demise of this imaginary SCC.

The difference would be twofold: first, the left would not find itself purchasing rule of law at the expense of its natural constituents (peasants, workers, the poor) as happened with the real SCC, trans-

25. "Random" neighborhood or "Ashwaiyyat" is a reference to informal slums emerging on public or private property in big urban centers in Egypt, living outside the reach of municipal regulation, whose inhabitants survive on economic transactions that are not recognized or accounted for by the formal economy of the state. See Ninette Fahmi, A Culture of Poverty or the Poverty of a Culture? Informal Settlements and the Debate over the State-Society Relationship in Egypt, 58 (4) MidDLE EAST JourNAL 597 (2004).

26. See Joel Beinin, The Struggle for Worker Rights in Egypt 26 -66 (2010).

27. Many economies of the public sector failed in the developing world because the national elites turned it into their own private "capital" through endemic corruption. Likewise in Egypt who capitalized the public sector, see JoHN WATERBURY, THE Egypt of Nasser and Sadat: The Political Economy of two Regimes 51 (1983); See Cypher \& Dietz, supra note 4 , at 253-58. 
forming itself into a mouthpiece for neo-liberalism (by default) via the rule of law route; and second, the uproar created by the demise of the SCC would have been louder and greater as its demise would have been associated with, and symbolic of, the demise of social groups who would have had a taste of the constitution on their side, no matter how brief the experience might have been. In other words, instead of the SCC's champions being brief-case-carrying, foreign-funding-dependent, social-base-deprived, easily-dispensable human rights activists, the supporters of the imaginary court would have been blocks of disenfranchised social groups whose mobilization by the court had given them the kind of social power the regime would have felt the need to contend with. Instead of departing with a peep, the imaginary SCC would have, I imagine, departed with a bang.

\section{The Trouble with the Real SCC}

With the fairy tale scenario in mind, we can locate the theoretical and political bias of the real SCC (and its class of commentator fans). The court's background assumption is that the market (private property) is both the proper form of democracy and its grand rule. And so, when the court through a series of decisions undoes "the distortion" of this rule from the previous historical eras (the Import Substitution Industrialization (ISI) era of the Egyptian economy), it not only proceeds to fix the economic incentives, it also gives democracy its natural form. But what if the proper place of the political democratic is precisely the opposite: the act of denaturalizing private property, which in the case of Egypt has taken the form of state-property-cumprivate-property (a failed ISI state)? We thus come to the conclusion that what undid the real SCC was the economics of its political jurisprudence (the market is the natural form of democracy) and the politics of its economic jurisprudence (the political demobilization of the economic losers). It is the latter that made the demobilization of the SCC itself the grand non-event of Egypt.

\section{Part Two: The Limit of ClS Analysis of Law as APPLIED TO THE SCC}

\section{A. Rule of Law as the Faith of the Left/the SCC Acting Cynically}

For distributional consequences to be the concern of the regime, because of their impact on the regime's security interests, and for the left to adopt a rule of law agenda at the expense of concern for distributional outcome, raises several questions as to the relationship between law, politics and ideology ${ }^{28}$ in the context of a post-develop-

28. By ideology I mean the means through which a dominant power may legitimate itself by promoting beliefs and values congenial to it; naturalizing and universalizing such beliefs so as to render them 
mental authoritarian state like Egypt (failed ISI embracing neoliberalism as the answer). These questions force us to tread on unfamiliar ground especially if we have the United States (a postindustrial capitalist democracy) in mind.

What strikes us in the comparison is that whereas in the case of the United States, the left performs the role of ideology critique in its approach to law to unmask its distributive impact and to de-center the dominant faith in the rule of law, in Egypt we find that faith in the rule of law is unmoored from its familiar dominant ideological status becoming mainly the faith of the left. This uncouples the left from its historical task (ideology critique) for two reasons: it is the left that has internalized the magical powers of the rule of law (i.e., opted for the illusion) and the illusion remains embattled (has yet to become hegemonic, thereby achieving the status of the ideological). ${ }^{29}$ In other words, who would do the critique and critique of what?

Moreover, why, what would be the point? In contrast to the situation in the United States, where ideology masks distributional stakes, the important role of critique, distributional stakes of the SCC's decisions fall where they may without any cover. By the time they hit the ground and before they go running, the government's arm reaches out and softens the fall in the name of security. ${ }^{30}$

Exacerbating this paradox is the fact that those who are making the rules (the judges of the SCC) are not the ones holding the faith in the rule of law. In fact, quite the opposite; strong textual and anecdotal evidence suggests that they are perfectly aware of what they are doing: manipulating the constitution to get the result they want. One doesn't even have to go down the route of searching for evidence of such cynicism. When the rule of law (of property) era is initiated through the establishment of a constitutional court, whose role it is to interpret a document such as the constitution where indeterminacy runs wild (especially if it's also socialist a la lettre before the 2007 amendment), it would be hard to imagine such a court in the grip of faith (bad or good). The SCC was loyally answering the historical call. The fact that it surprised the regime with its assault on its political

self-evident and apparently inevitable; denigrating ideas which might challenge it; excluding rival forms of thought, perhaps by some unspoken but systematic logic; and obscuring social reality in ways convenient to itself. Such "mystification" as it is commonly known, frequently takes the form of masking or suppressing social conflicts, from which arises conception of ideology as an imaginary resolution of real contradictions. In any actual ideological formation, all six of these strategies are likely to interact in complex ways.

See Terry Eagleton, Ideology: An Introduction 5-6 (1991).

29. While the faith in the Rule of Law is popular as the Egyptian revolution has clearly shown, it has yet to be adopted by a recognized "dominant power" through which it legitimates, naturalzes and universalizes its interests.

30 . The government does so by either increasing repression or making distributive concessions or both. 
tranquility does not deny that fact, it simply adds an interesting wrinkle.

Perhaps confronting one's power without the mediation of faith regresses one back to infancy, for on close reading of many of the Court's decisions, especially those on taxes in which the court proceeds to annul millions of dollars of revenue for the government based on tenuous textual support, one can't help but notice foolish play. It is the kind of foolish play that comes from doing politics without taking responsibility, ruling without ruling. Children may very well be the biggest cynics: wreaking havoc, acting omnipotently and yet, maybe even as a result, adored.

Comes Mommy ${ }^{31}$ mopping the floor ...

\section{B. Security: Ideology and its Critique Combined}

In contrast to the role that ideology plays in the United States, naturalizing the distributional fall-out, "security considerations" in Egypt are designed to confront distributional stakes head on. Indeed the genius of "security" is that it acts as an ideology substitute (denaturalize what you like, just don't act on it) while also making ideological critique superfluous (distributional fall out is the concern of security). Political scientists like to assert that because authoritarian regimes are deprived of the legitimacy of democratic process (form) they have to rely on the legitimation of distribution (substance) to retain their hold on power. ${ }^{32}$ But of course, there is always a surplus of grievance, especially when the transition to private property wreaks havoc among traditional beneficiaries. In this case, "security" has to step in to perform the role of ideology, albeit with a difference: instead of inserting itself in the interstices of your brain the way ideology does, it inserts itself in the interstices of institutions, to make sure grievances that may exist remain just that: grievances. It promotes and it demotes, it renders famous and renders invisible, it pats on the shoulders and tortures in the groins, it enriches and it exiles. ${ }^{33}$ It is ideology physicalized, embodied. Rather than relying on its absence to be effective, it is eminently and openly present. It doesn't want you to believe, it knows that you don't: it just wants you to hold still.

31. See supra note 11 .

32. See generally Brian Downing, Military Revolution and Political Change: Origins of Democracy and Autocracy in Early Modern Europe (1993); Carl J. Friedrich, Totalitarian Dictatorship and Autocracy (1965); Ralph K. White, AuTOCRACY AND DEMOCRACY: AN EXPERIMENTAL INQUIRY (1960); RULE By LAW: JUDICIAL Politics in Authoritarian Regimes (Tom Ginsburg \& Tamir Moustafa eds., 2008).

33. Younis argues that the security forces can not exercise its political role on legal grounds but by direct coercion or indirectly through state related / dependent institutions. See SHERIF YounIS, ISTIKLAL El-QADAA' [INDEPENDENCE OF THE JUDICIARY] 52 (2007). 
This command at a distance to be met by holding still is what makes "security" both heavy and empty at the same time. Its command is heavy (don't or else) but it is also empty because it is indifferent to what you really think. Compare that to ideological interpellation in the United States: it is light yet full. It wants your mind, fills you up and so acquires the lightness of your private being. It is you!

\section{The Open Scandal is not so much Legal Indeterminacy but Lack of Judicial Autonomy}

And so the open secret in Egypt is not so much the indeterminacy of the legal text, i.e., that ideology influences the interpretive work of the judge, as is the case in the United States. It is rather that the judge was appointed and/or promised rewards and/or intimidated by security services and/or allowed security considerations to influence his decisions. In other words, the open secret in Egypt is that this universal judge allowed his technocratic skills to be spoiled and stained by "security considerations." ${ }^{34}$ Whereas in the United States, the rebellious judge is the one who (always secretly) abandons his "bad faith"35 and submits to ideological influence without the mediation of bad conscience, and self-consciously manipulates the text (within the constraints of that remainder of determinacy, of course). In Egypt, the rebellious judge, by contrast, is one who resists influence by either staring the displeasure of the security services in his rulings in the face (risking loss of rewards, demotion, transfer), or rebels against his situation and that of his colleagues writ large. In the second instance, the judge is a true hero protesting the system in toto. In a Superman-like fashion, he takes off his technocratic uniform and dons in its stead a rather strange, tight and uncomfortable garb: the political.

Taking to the streets, the judge protests vehemently the interference of security forces within his work (and is of course met by an adoring public). ${ }^{36}$ This excursion into the political is tolerated only because it is understood (by the adoring public) to be temporary and

34. Younis raises the question, are the Judges' demand for the independence of the judiciary regarded as politics? And are judges politicized? And immediately he notes that to some extent the answer is positive. Furthermore, he argues that they should be under the circumstances of authoritarianism. See id., at 60-66.

35. "Bad faith" refers to a type of consciousness shared by judges whereby they deny to others as well as to themselves that they are adjudicating "ideologically." See DUNCAN KENNEDY, CRITIQUE OF ADJUDICATION 191-212 (1998).

36. Two activist judges published an article under the title "When Judges are Beaten," addressing their protest, demands and democratic aspirations. See Mahmud Mekki \& Hisham Bastawisi, When Judges are Beaten, The Guardian, May 10, 2006, available at http://www.guardian.co.uk/commentisfree/2006/may/10/comment.egypt (last visited July 20, 2011). See also NATHAN Brown \& Hesham NASR, EGYPT's JudGES Steps Forward: The Judicial Election Boycutt and Egyptian Reform (2005). For further details about the Judges protest, see BBC news, May 25, 2006, on "Egyptian 
coerced. The protesting judge is out there righting the wrong of external influence, despite his best judgment and against the grain of his professional training, "but hey, somebody has to do it!" Once the protest is over, it is understood by all that our heroic judge will return to his chambers, put his judicial robe and technocratic gloves back on, and return to his natural calling. This is how terrible the rule of security is: it forces technocrats to become political, to be thrown out to suffer the merciless sun of the political when their pale genteel judicial skin could not otherwise tolerate it. ${ }^{37}$

As in the example of the heroic judge above, the popular struggle for judicial autonomy in Egypt is sustained by the belief that the obverse of the technocratic is the political. What needs to be vehemently resisted and what stands in the way of Egypt becoming a modern state, it is widely believed especially among the left, is that security meddles, indeed inserts itself inside the state's institutional structures, most terribly in the case of the judiciary, whose ideal role is to act as the objective and neutral arbiter of disputes between individuals, and between individuals and the government. ${ }^{38}$ Yet, spend any time in Egypt and you quickly come to the conclusion that in the context of Egypt, the technocratic does not act as the obverse of the political, in the sense of its opposite. Instead, it is the other form in which the political appears, its exchangeable identical twin. It has been often noted by political scientists that authoritarian rulers of the Arab world go out of their way to ground their rule in law. ${ }^{39}$ In a universe where ideology is thin and "security considerations" fill the remaining void, the technocratic short-circuits its way to the political (and vice versa) without the lubricating role of the ideological as is the case in the United States. And it is this disavowed third term, the ideological, that sustains, in my view, the distinction in the case of the United States and makes the political a real risk for the techno-

Judges come out in force" available at http://news.bbc.co.uk/2/hi/middle_east/ 5017508.stm (last visited July 19, 2011).

37. Younis, supra note 33 , at 62 .

38. $I d$.

39. Brown shows how the Arab authoritarian regimes appeal to constitutional principles in the effort to make the regimes more accountable. He demonstrates how rulers can use rule of law to strengthen their rule. See Brown, The RULE OF LAW IN THE ARAB WorLd, supra note 9. Some called the Arab authoritarian regimes a "liberalized Autocracy"; see Daniel Brumberg, Democratization in the Arab World? The Trap of Liberalized Autocracy, 13 (4) Journal of DEMOCRACY 56 (Oct. 2002). In his article, Brumberg argues:

Liberalized autocracy has proven far more durable than once imagined. The trademark mixture of guided pluralism, controlled elections, and selective repression in Egypt, Jordan, Morocco, Algeria, and Kuwait is not just a "survival strategy" adopted by the authoritarian regimes, but rather a type of political system whose institutions, rule, and logic defy any linear model of democratization.

Id., at 56. 
cratic, its de-legitimating stain. Critical Legal Scholars have often insisted, against the grain of popular fiction, that their claim is not that Law is Politics (that judges rule on political grounds), but rather that ideological influences insert themselves in the interpretive work of the judge especially when the judicial experience of textual constraint is at its weakest. In fact, ideological influence is the very condition for the emergence of judicial autonomy: it is through denying its work that members of the judiciary come to acquire their unique consciousness as a professional class, their universalized bad faith, their autonomy from the political.

Perhaps the tragedy of the Egyptian judiciary is not so much that its appointment is tainted by the approval of security services, instead (and even in cases when it's not) it is that "security" as a mediating term between the legal and the political is both too heavy and too empty to allow the judiciary the bliss of denial. As I mentioned above, security considerations can be summed up by the command "don't!" By not aspiring to fill the mind of judges with anything (except perhaps terror), it has deprived them of the work that comes with denial of influence. And without (partial) denial there is no judicial autonomy. The irony is that a heroic judge can protest on the street the pernicious influence of security services on their work, but the heavy emptiness of "security considerations" as an ideology substitute cannot be protested against. It is structural to the system, specifically to its political economy.

\section{Part Three: Security as an Ideology Substitute: A History}

Authoritarianism in the Arab world is often referred to in mystical terms. While authoritarianism abounds in the world, we are told, the uninterrupted and obstinate quality of this system in the Arab case is decidedly unique. ${ }^{40}$ Latin America has turned democratic, Africa has had its brush with serious democratic experimentation, and half of Asia is democratic (India alone!), but not the Arab world! Sure enough, Arab regimes introduce identifiably democratic practices and institutions (elections, parliaments, constitutional courts, human rights commissions, freedom of the press laws, etc.), but every time gestures of this sort are made and before anybody exhales, they are quickly withdrawn, recast, reinterpreted. Soon enough it transpires that these trappings are nothing but a ruse of a given regime, halfhearted maneuvers by the state elites, designed to either steer a transition in the economy of sorts that seemed threatening to the regime's hold on power; or to respond to external pressure so that the regime, rather than introducing new means for power turnover, can retain its power by changing its ways of governance. Democratic institutions,

40. Some called it "Arab political exceptionalism"; see Larry Diamond, Why are there no Arab Democracies?, 21 (1) Journal of Democracy 93 (Jan. 2010). 
rather than being the negation of authoritarian rule, turn out to be, over and over again, its new form.

The reason I call this account mystical (mystifying, mystified, especially misty) is because it locates the property of "authoritarianism" outside the political economy as it moves on historically (contrary to popular wisdom, history does its work even in Arabia). In a previous article, I argued that in Egypt three political economies are being staged: (failed) ISI economy turned neo-liberal with intermittent intervention of rentierism. ${ }^{41}$

While ISI as a developmental strategy was premised on the idea that the rise of the urban industrial working class would come at the expense of the peasant (whose goods sold to government were discounted), this only took place after the peasant came upon an asset (land) that he didn't own before, i.e., as a result of the agricultural (land) reforms of the early $1950 \mathrm{~s},{ }^{42}$ accompanied by government subsidized agricultural loans, seeds, equipment, damn water, etc. ${ }^{43}$ "Nationalist socialism" as mobilizational ideology seemed at the time to have a rational basis in its distributional approach-the pie was on its face fairly distributed. Failed ISI was symptomatized by the failure of the emergence of competitive industrialization leading to affluent urbanization and mechanization of the countryside, as originally planned. The emergent wealth of the state elites (managing corruptly the expanded public sector of the ISI) came in conjunction with the rude interruption of the upward mobility of the urban and newly educated (in state schools and colleges) working class as well as increasing impoverishment of the rural peasants. Slowly but surely a reciprocal encroachment took place: the impoverished city encroaching on the failed countryside and an impoverished peasantry encroaching on an unemployed urban space creating the peasant urban slums of Al-Ashwaiyyaat (the random neighborhoods). The notable gap in wealth between the few (state elites and those fortunate enough to be incorporated in their patronage network) and the many (everybody else) became a serious stain on the credibility of the system. An ideological void occurred: nationalist socialism lost its rationalizing power.

If an ideological void is created when the gap in wealth is naked to the consciousness of the national audience, the void has to find a filler if political rule can achieve stability. An alternative to the ideol-

41. See generally Lama Abu Odeh, On Law and the Transition to Market: The Case of Egypt, 23 Emory INT'L L. REv. 351-81 (2009).

42. See Hamid Ansari, EgYPt: The Stalled Society 79-87 (1986); T. Khattab, Land Law, in EGYPT AND ITS LAws 126-27 (Nathalie Bernard-Maugiron \& Baudouin Dupret eds., 2002).

43. See Galal A. Amin, Egrpt's Economic Predicament: A Study in the Interaction of External Pressure, Political folly, and Soclal Tension in Egypt, 1960-90 (1995). 
ogy void filler would of course be to fill the wealth gap itself. Socialism comes closest to this instance, in my view, but so does rentierism, the strange and opposite twin of socialism. It is a prevailing economic system in the Arab world, with its representative instance in Egypt, although on a reduced scale. In the rentier model, the government budget has access to revenue through sale in international markets of a highly strategic commodity such as oil (in the case of Egypt, it also includes Egypt's geopolitical importance to the United States yielding it USAID money, as well as revenue from the Suez canal) that requires a minimum of labor, domestic or international, to produce it. This produces the phenomenon of "bounty capitalism": rather than closing the wealth gap, as its strange twin socialism would do, it rewards its essentially non-laboring nationals in a way a socialist system would (needs met from the cradle to the grave), while still creating the outrageously wealthy few (as is most noticeable in Saudi Arabia). Rentierism acts as a socialist state distributionally by virtue of the size of its revenue while still producing capitalist effects (wealth disparity) with the important added complexity that it does so without the mediation of local labor. ${ }^{44}$ The lack of mediation of local labor makes the connection to the state direct and unmediated by ideology. Put differently, the non-laboring citizen of a rentier state demands distribution directly from the state, as a citizen, and the state, owner of wealth, giveth and taketh away without obligation towards its citizens as producers. Its bounty is therefore experienced by the citizens as both arbitrary and undeserved at the same time, i.e., almost mystical. Just as the source of the wealth itself (oil) seemed to fall from the sky (or rather flow from earth) like manna from heaven (or fountains of black liquid), so does the state in giving and withholding-it acts as mysteriously and arbitrarily as the God that randomly chose the people of Arabia to enjoy His manna.

The rentier aspect of the Egyptian economy was not substantial enough as a share of the over all economy to allow the regime to make a secure shift to neo-liberalism, by using rentier revenue to compensate or bribe enough of the losers into silence. It was nevertheless substantial enough to sustain a large civil service workforce (numbering seven million), which, strangely enough, seemed to expand in size the more the government privatized its public holdings. ${ }^{45}$ The size of the civil service bribe was for a large number of beneficiaries barely sufficient to eke out a living, leaving a good part of them (especially the retirees) to lead an existence on the edge of pauperization. But as

44. See generally Nazih N. Ayubi, Over-Stating the Arab Sate: Politics and Society in THE Middle EAst (1996).

45. See generally Samir Sulayman, Al-Nizam AL-Qawiyy Wal-Dawla AlDha'fiyya [The Strong Regime and the Weak State] (2005). 
beneficiaries of the state's bounty, they constituted the passive base of support for the authoritarian regime: support because they feared real pauperization if they protested; passive, because their income barely kept up with the rise in prices that came with neo-liberalism. Their support of the regime was direct and unmediated by ideology, based on the trade-off of passive consent for precious benefits in a sea of increasing overall pauperization.

The rest of the discontented? Some traveled as (beggar) migrant labor to the rest of the Arab world. Through departure, they were spared the workings of "security considerations" (except on the borders) while their remittances added to the rentier manna the state could use to silence protest. As for that large remainder of raging discontent, there was the two million people employed by the Egyptian security forces. They intimidated, threatened, harassed, humiliated, arbitrarily arrested, jailed, and tortured those who dared protest. If ideology means a discourse that legitimizes the winnings of the winners in the eyes of the losers, there was little of that to be found.

\section{ConCLUSION}

In this article I argued that a court that liberalizes on the economic front and the political one at the same time in the context of an authoritarian system that is hostile to the Court's autonomy ends up, by dragging the left in its defense as it struggles to preserve this autonomy, compromising the distributional agenda of this left. What is given up by the left in agenda gets picked up by the authoritarian regime as policy necessary to preserve the stability of domination and control. When distribution moves to the authoritarian regime's side, it gets articulated as "security consideration" denoting both welfare concessions to the newly impoverished as a result of the liberalization of the economy and coercive suppression of dissent on their part. A court that then adjudicates in the shadow of "security considerations" is an institution that is a short distance to acting politically no matter how formalist its legal reasoning might sound. It is a court that reads the law without the thick buffer of ideology, leaving us as critics of the court with no "behind" to search for as we study its decisions. 
